\title{
Trappability and the Distribution of Individual Captures in a Common Vole Population ${ }^{1}$
}

\section{Leszek NABAGŁO, Krystyna A. ADAMCZEWSKA-ANDRZEJEWSKA \& Regina MACKIN-ROGALSKA}

\begin{abstract}
Nabagło L., Adamczewska-Andrzejewska K. A. \& Mackin-Rogalska R., 1984: Trappability and the distribution of individual captures in a common vole population. Acta theriol., 29, 12: 159-166 [With 1 Table \& 3 Figs.]

Trappability and the distribution of individual captures were examined for three populations of the common vole Microtus arvalis (Pallas, 1779). Trappability was generally low, but relatively higher in summer than on the turn of spring and summer and in autumn. In summer, the trappability of females was higher than that of males. In other periods this difference disappeared. Trappability was lower on grids with low than tall plant cover. The distributions of individual captures were skewed, with the highest proportions of individuals captured only once. The empirical distributions differed from the corresponding Poisson distributions. It is indicated that more efficient methods of common vole trapping should be developed. The relevance of trappability study in the $M$. arvalis population to analysis of social structure and individual differentiation in behaviour among voles is discussed.

[Dept. of Vertebrate Ecology, Institute of Ecology, Polish Academy of Sciences, 05-092 Dziekanów Leśny, Poland].
\end{abstract}

\section{INTRODUCTION}

In population studies of small rodents the CMR (Catch-Mark-Release) method is commonly used. The results obtained by this method largely depend on trappability and individual differences in the trappability of animals. These differences can be an important source of information on the social structure of rodent populations (Andrzejewski et al., 1959; Calhoun, 1959; Gliwicz, 1970, 1979). So far only sex-related differences. and seasonal changes have been found in the trappability of the common vole Microtus arvalis (Pallas, 1779) (Grunwald, 1975). According to Malinowski \& Nabagło (1978), the distribution of common vole captures was random. When captures are random, no matter what method is used, they do not provide basis for analysing individual differences in behaviour, nor the social structure of the population.

The purpose of this paper is to estimate the trappability of common voles in a free-living population. Long series of observations were used, comprising $12-20$ trap inspections, to find whether or not the distribution of captures continue to be random as in the case of short series made up of four inspections in the experiment of Malinowski \& Nabagło (1978).

1 Badania wykonano w ramach problemu MR II 15 , temat 01.03 .05 , koordynowanego przez Instytut Ekologii PAN. 


\section{STUDY AREA, MATERIAL AND METHODS}

The study was carried out in crop fields of the Animal Husbandry and Agricultural Station at Plochocin, near Warsaw. Three 0.5 -ha study plots were established in several-hectar crops. Two of them were located on adjoining fields of alfalfa in the third year (denoted by AI and AII), and the third plot was on a grazed pasture (denoted by $\mathrm{P}$ ) at a distance of about two $\mathrm{km}$. The crops were subject to usual agrotechnical treatments.

In the alfalfa crop the study was conducted from April to November, 1981, and in the pasture from June to Novernber, 1981. A grid of 225 trapping points, evenly spaced $5 \mathrm{~m}$ apart in both directions, was established. At each point one live-trap was set by the end of June and two traps later. These were standard wooden live-traps with oat bait. Five series of captures in the alfalfa crop were done over the study period. On the two crop fields, alfalfa was low in April and November, and on the plot AI it was mown in June. In the other study periods, alfalfa was tall. In the pasture, there were four series of captures, each time at a low plant cover.

In each series, traps were set for 10 days, and inspected twice a day (in the morning and in the evening). On sunny days, when the air temperature exceeded $28^{\circ} \mathrm{C}$ and traps were not shaded by vegetation, they were set over the night and inspected only in the morning. For this reason there were differences in the number of trap inspections from one grid to another in the same period.

The CMR method was used. The voles captured for the first time were marked by toe clipping. On each capture, the individual number and sex were noted, as well as the date of capture.

As many as 759 females and 712 males were marked on grid AI, 508 females and 462 males on AII, and 111 females and 107 males on grid P. The respective numbers of captures were 1883 and 1713 on AI, 1716 and 1336 on AII, and 219 and 172 on P. The voles trapped on the alfalfa grid in April and on the pasture grid in June are excluded from the present analysis because of a very low population density at that time.

\section{RESULTS}

Trappability, defined as a probability of capture of an individual per trap inspection, was calculated from Andrzejewski's (1969) formula

$$
p=\frac{c}{a \cdot N}
$$

where $p$ is trappability, $c$ is the number of captures per series of captures study period, $a$ is the number of trap inspections, and $N$ is the number of individuals recorded per series of captures.

The frequency distribution of individual captures was calculated. In each series and on each grid, calculations for males and females were made separately.

The trappability of common voles was low, and it ranged from 0.07 to 0.227 (Table 1). The highest trappability was recorded on the two alfalfa grids in July. It decreased in autumn (September and November). In June, trappability was lower on newly-mown alfalfa grid (AI) than on unmown alfalfa grid (AII). 
Table 1

Trappability of the common vole populations inhabiting alfalfa crops (AI and AII) and a pasture (P).

1 - the number of trap inspections, 2-the number of individuals, 3 - trappability as a probability of capture per individual per trap inspection (see text p. 160).

\begin{tabular}{|c|c|c|c|c|c|c|c|c|c|c|}
\hline \multirow{2}{*}{ Month } & \multirow{2}{*}{ Sex } & \multicolumn{3}{|c|}{ AI } & \multicolumn{3}{|c|}{ AII } & \multicolumn{3}{|c|}{$\mathrm{P}$} \\
\hline & & 1 & 2 & 3 & 1 & 2 & 3 & 1 & 2 & 3 \\
\hline \multirow[t]{2}{*}{ June } & F & 12 & 33 & 0.119 & 20 & 61 & 0.159 & - & - & - \\
\hline & M & & 40 & 0.122 & & 98 & 0.177 & & - & - \\
\hline \multirow[t]{2}{*}{ July } & $F$ & 19 & 213 & 0.227 & 19 & 134 & 0.204 & 12 & 35 & 0.195 \\
\hline & $\mathrm{M}$ & & 207 & 0.178 & & 140 & 0.195 & & 24 & 0.198 \\
\hline \multirow[t]{2}{*}{ Sept. } & $\mathrm{F}$ & 19 & 289 & 0.164 & 19 & 182 & 0.202 & 19 & 53 & 0.102 \\
\hline & $\mathrm{M}$ & & 238 & 0.111 & & 122 & 0.124 & & 57 & 0.071 \\
\hline \multirow{2}{*}{ Nov. } & F & 19 & 210 & 0.166 & 19 & 127 & 0.122 & 15 & 23 & 0.098 \\
\hline & M & & 225 & 0.106 & & 101 & 0.093 & & 66 & 0.09 \\
\hline
\end{tabular}
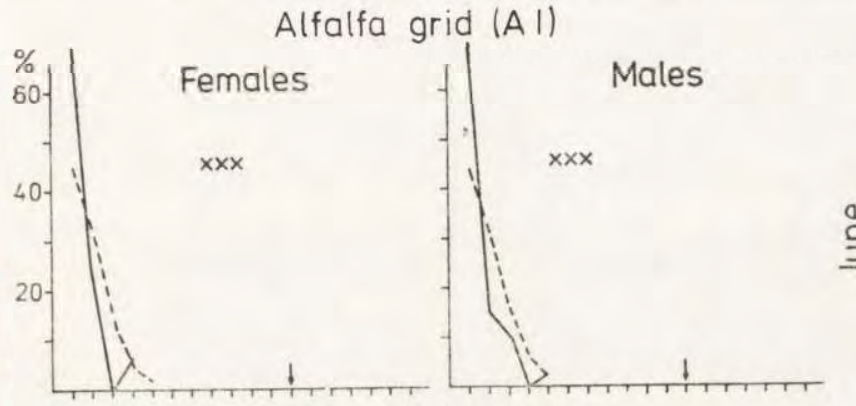

$\stackrel{\Perp}{\stackrel{5}{丂}}$
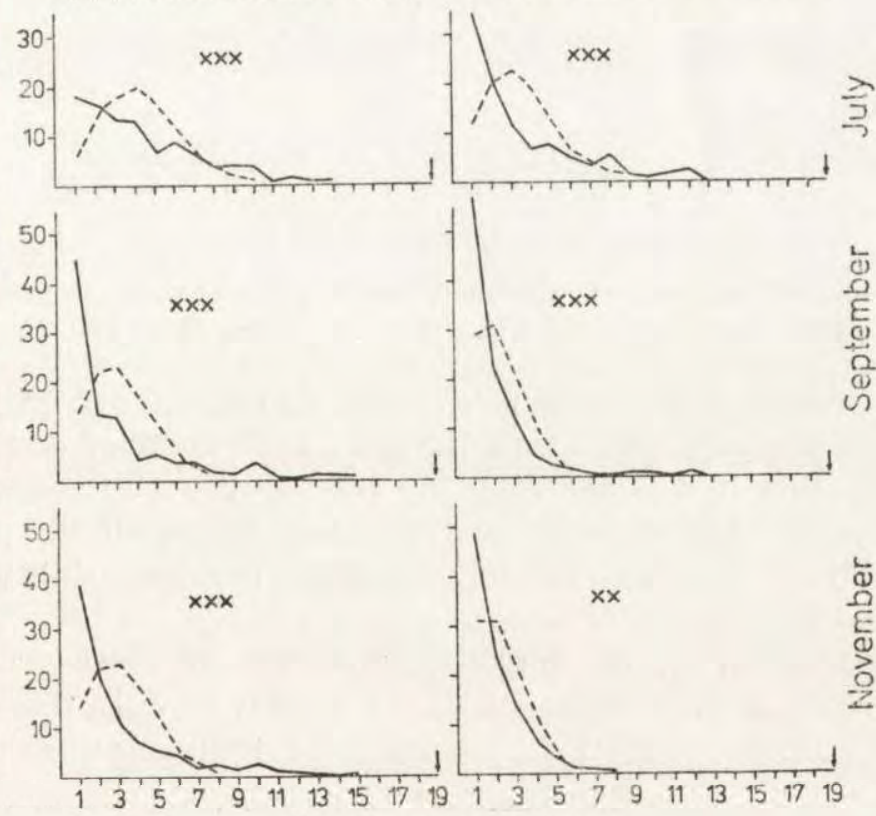

No. of catches / indiv.

Fig. 1. Frecquency distribution of individual captures in the common vole population (explanation concluded on p. 162).

Acta theriol. 2 

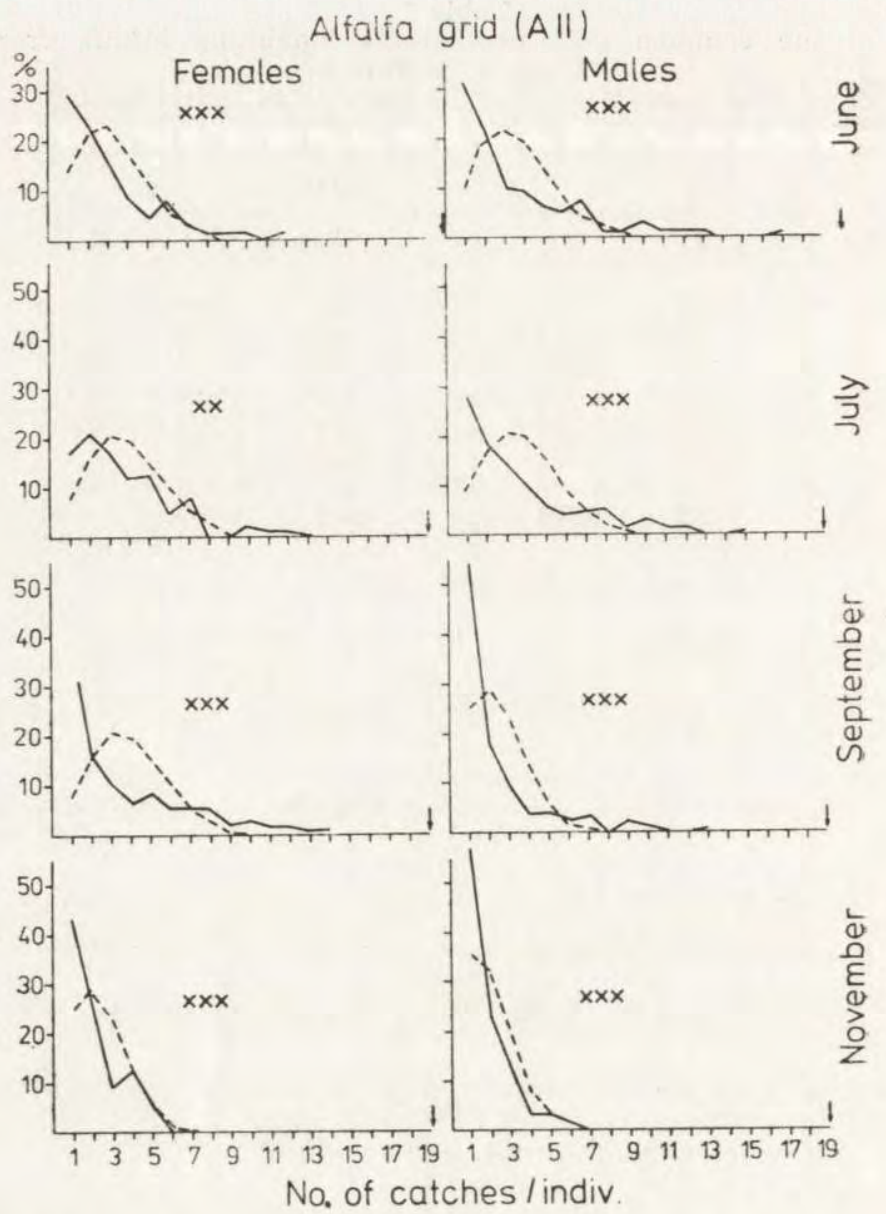

Fig. 2, Frequency distribution of individual captures in the common vole population. See explanation for Fig. 1 (at the bottom of p. 162).

The trappability of common voles tended to be higher on the alfalfa grids than on the pasture grid, particularly in September and November (Table 1). In July and September, the trappability of females was statistically significantly higher than that of males in all the populations (Table 1). The $\chi^{2}$ test was used to compare the trappability of males and females.

In a trapping series, the highest proportion of voles was captured only once, and only for females trapped on AII in July this proportion was slightly lower than the proportion of individuals captured two

Solid line - empirical distribution, dashed line - Poisson distributions. Statistically significant distributions are determined at ${ }^{*} P>0.05,{ }^{* *} P>0.01$, and ${ }^{* * *} P>0.001$. Arrows on the $x$-axis indicate the number of trap inspections during a given time. 

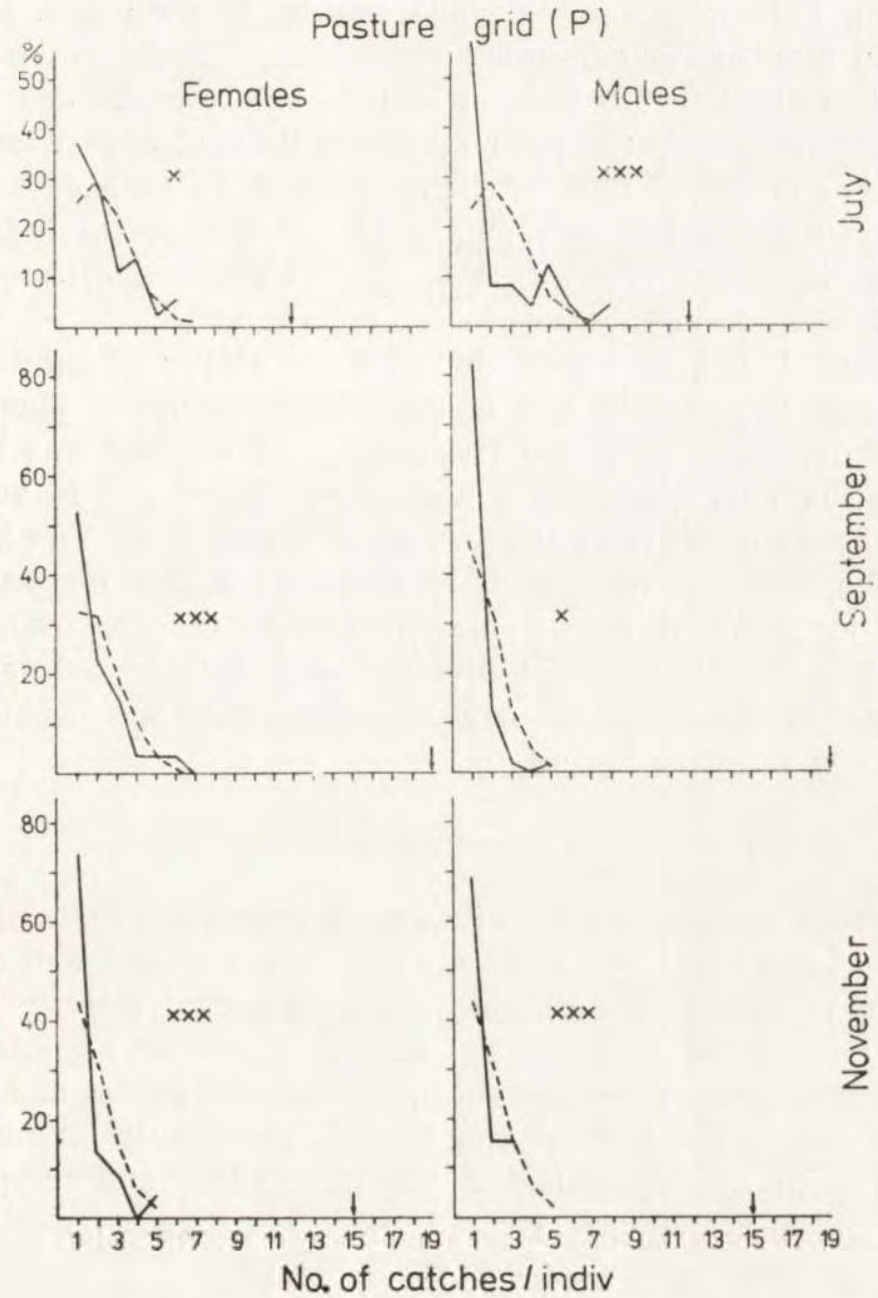

Fig. 3. Frequency distribution of individual captures in the common vole population. See explanations for Fig. 1 (at the bottom of p. 162).

times (Figs. 1, 2, 3). The proportion of voles trapped 2, 3, 4, and more times declined. This decline was rapid when the trappability was low (less than 0.1), or when a trapping series consisted of less than 19 trap inspections. In such cases more than $90 \%$ of individuals were trapped at most two times, and the highest number of captures of a vole was 5 . Such a distribution of individual captures was obtained for population $\mathrm{P}$ in September and November, and for population AI on the mown alfalfa grid in June (Figs. 1, 2, 3). In other cases, differences in individual captures were higher, and the highest number of captures was 17 per 19 trap inspections (a male on AI in July) (Figs. 1, 2, 3).

A theoretical distribution of individual captures was calculated assuming that voles were trapped randomly according to the Poisson 
distribution. Calculations were made separately for males and females using mean numbers of captures per trapping series on each grid. Since the empirical distributions did not include voles not trapped at all over the study period, truncated (without zeros) theoretical distributions were used for comparison, the $\chi^{2}$ test being applied. In each case, the difference between theoretical and empirical distributions of indivdual captures were significant (Figs. 1,2,3). Thus individual differences in the number of captures in each serie were not random.

To sum up, it can be stated that the probability of capture declined from summer to autumn, and increased with growing plant cover. In summer (July, September) the trappability of females was higher than males. On the turn of spring and summer (June) and in autumn (November), the trappability of the two sexes was similar. The highest proportion of voles was trapped only once. At a low trappability they accounted for $80 \%$ of the population and at a high trappability for $20-30 \%$. The distribution of individual captures was not random. This may imply, for example, that population structure has an effect on the trappability of individual voles.

\section{DISCUSSION}

A decrease in the trappability of common voles from summer to autumn has already been noted by Grunwald (1975), and interpreted as a decline in mobility related to the disappearance of sexual activity in autumn. If this is true, differences in trappability should be expected between sexually active and non-active voles, or between young and adult individuals, at any given time of the season. The results of many studies show that both age structure of the population and proportions of sexually active individuals largely vary in different periods of the season (Adamczewska-Andrzejewska \& Nabagło, 1977; Pelikán, 1959). But neither Grunwald (1975) nor Malinowski \& Nabagło (1978) have recorded individual differences in the trappability of common voles. It seems that the method used in those studies precluded the distinction between individuals differing in trappability. The present results suggest that only long series of observations may provide basis for such a distinction, indicating that the distribution of individual captures was not random.

The total trappability of common voles in this study was very low (from 0.07 to 0.23 ), as compared with that for other rodents such as Clethrionomys glareolus (0.40), Apodemus flavicollis (0.32), and Apodemus agrarius (0.38), captured in identical traps by Andrzejewski (1963), Andrzejewski et al. (1967), and others. Moreover, the proportion of voles trapped only once was high. Thus, the amount of information on individual common voles obtained by the $C M R$ method is very low, and it is difficult to get a reliable estimate of numbers, or home range size, 
or to analyse population structures and processes. In view of this it seems that the future studies will require even longer series of observations, or more efficient methods of capture.

Andrzejewski et al. (1959), Calhoun (1959), Gliwicz (1970, 1979), and others argue that individual differences in the trappability among population members can provide useful information on the social structure of rodent populations. Data on the behaviour of $M$. arvalis are rather scarce. Chełkowska (1978), for example, described changes in the tolerance of conspecifics, related to seasonal changes in the intensity of reproduction. De Jonge (1983), who observed laboratory raised voles, noted strong family bonds and a heavy competition between families. $\mathrm{He}$ emphasized the importance of odour to individual identification in common voles (which is greater than in C. glareolus or M. agrestis). It is known from the studies on other rodent species that the odour of earlier trapped individuals, emanating from traps, can largely influence trappability (Rowe. 1970; Pelikán, 1959). The present results and discussion show that also the trappability of the common vole can be used in the studies on social structure and behavioural differences among population members. So far such studies have not been conducted in freeliving common vole populations.

Acknowledgements: We wish to thank Dr. Janusz Uchmański for calculating the Poisson distributions.

\section{REFERENCES}

1. Adamczewska-Andrzejewska K. A. \& Nabagło L., 1977: Demographic parameters and variations in numbers of the common vole. Acta theriol., 22: $431-457$.

2. Andrzejewski R., 1963; Process of incoming, settlement and disappearance of individuals and variations in the numbers of small rodents. Acta theriol., 7; 169-213.

3. Andrzejewski R., 1969: Analiza wyników polowów drobnych ssaków metodą „Kalendarza złowień". Zesz. nauk., 2: 1-104. Warszawa.

4. Andrzejewski R., Petrusewicz K. \& Walkowa W., 1959: Preliminary report of results obtained with a living trap in a confined population of mice. Bull. Acad. pol. Sci., Cl. II, 7: $367-370$.

5. Andrzejewski R., Petrusewicz K. \& Waszkiewicz-Gliwicz J., 1967: The trappability of Clethrionomys glareolus (Schreber, 1780) and other ecological parameters obtained by CMR capture method. Ekol, pol. A, 15: 709-725.

6. Calhoun J. B., 1959: Revised sampling procedure for the North American Census of Small Mammals (NACSM). Nat. Inst. of Cental Health, Bethesda, 10: $1-12$.

7. Chełkowska H., 1978: Variations in numbers and social factors in a population of field voles. Acta theriol., 23: 213-238.

8. Gliwicz J., 1970: Relation between trappability and age of individuals in a population of the bank vole. Acta theriol., 15: 15-23.

9. Fliwicz J., 1979: Struktura wiekowa a organizacja socjalna gryzoni. Wiad. ekoi., 25: 9-17. 
10. Grunwald H., 1975: Changes in trappability of common vole. Acta theriol., 20: $333-341$.

11. Jonge de G., 1983: Aggression and group formation in the voles Microtus agrestis, $M$. arvalis and Clethrionomys glareolus in relation to intra- and interspecific competition. Behaviour, $84: 1-73$.

12. Malinowski W. \& Nabagło L., 1978: Distribution of probability of catching individuals of a closed Microtus arvalis (Pall., 1779) population. Bull. Acad. pol. Sci., Cl. II, 26: 145-150.

13. Pelikán J., 1959: Rozmnožováni, populačni dynamika, a přemnožováni hraboše polniho. [In: Hraboš polni, Microtus arvalis, eds. J. Kratochvíl]. Ceskoslov. Akad. Véd: $130-179$. Praha.

14. Rowe F. P., 1970: The response of wild house mouse (Mus musculus) to live traps marked by their own and by foreign mouse odor. J. Zool., 162: 517-520.

15. Summertin C. T. \& Wolfe J. L., 1973: Social influence on trap responce of the cotton rat Sigmodon hispidus. Ecology, 54: 1156-1159.

Accepted, March 30, 1984.

Leszek NABAGŁO, Krystyna A. ADAMCZEWSKA-ANDRZEJOWSKA

i Regina MACKIN-ROGALSKA

ŁOWNOSC I ROZKŁAD OSOBNIKOW POD WZGLĘDEM LICZBY ZŁOWIEN W POPULACJI NORNIKA ZWYCZAJNEGO

\section{Streszczenie}

Zbadano lowność i rozkład osobników pod względem liczby złowien $w$ trzech naturalnych populacjach $M$. arvalis. Stwierdzono ogólnie niską łowność osobników przy czym stosunkowo najwyższą latem, niższą zaś na przełomie wiosny i lata oraz jesienią (Tabela 1). Latem lepiej łowiły się samice niż samce, w pozostałym okresie łowność osobników obu płci była podobna (Tabela 1). Zaobserwowano tendencję do gorszego lowienia się osobników żyjących na uprawie $\mathrm{z}$ niska pokrywą roślinną $\mathrm{w}$ porównaniu do terenu porośniętego wysoką uprawą. Rozkłady osobnikow pod względem liczby złowień miały charakter skośny a największy udzial $w$ populacjach stanowily norniki zlowione tylko jeden raz (Ryc. 1, 2, 3). Eksperymentalne rozkłady osobników pod względem liczby złowień różniły się statystycznie istotnie od odpowiadających im rozkładów teoretycznych Poissona (Ryc. 1, 2, 3). Wskazano na konieczność poszukiwania skuteczniejszych metod lowienia norników. Przedyskutowano przydatność wyników o łowności osobników w populacji $M$. arvalis do badania struktury socjalnej i zróżnicowania norników pod względem ich behavioru. 